\title{
Penerapan model pembelajaran problem based learning untuk meningkatkan hasil belajar peserta didik SMAN 1 Kembang
}

\author{
Allif Silfiyana Rohman \\ Pendidikan Fisika, Universitas Negeri Semarang, Indonesia \\ Surat-e: silfiyanaallif830@gmail.com \\ Wiyanto \\ Pendidikan Fisika, Universitas Negeri Semarang, Indonesia \\ Surat-e: wiyanto@mail.unnes.ac.id

\section{Budi Astuti} \\ Pendidikan Fisika, Universitas Negeri Semarang, Indonesia \\ Surat-e: b_astuti79@mail.unnes.ac.id
}

\begin{abstract}
Abstrak. Penelitian ini bertujuan untuk mengetahui hasil belajar kognitif peserta didik menggunakan model pembelajaran Problem Based Learning (PBL). Jenis penelitian yang digunakan adalah Penelitian Tindakan Kelas (PTK) dengan pendekatan kualitatif. Penelitian ini dilakukan secara daring melalui Google Meet dan Whatsapp Group selama dua siklus. Adapun kegiatan penelitiannya meliputi perencanaan, pelaksanaan, observasi/evaluasi dan refleksi. Subjek penelitian ini adalah peserta didik kelas X MIPA-3 SMAN 1 Kembang. Teknik pengambilan data menggunakan tes dan wawancara kemudian di analisis secara kualitatif. Hasil penelitian yang diperoleh yaitu pada Siklus I terdapat 57\% peserta didik yang mencapai kriteria ketuntasan dan terjadi peningkatan pada Siklus II sebanyak $77 \%$ peserta didik telah mencapai kriteria ketuntasan. Peningkatan kriteria ketuntasan tersebut dapat terjadi karena guru memberi motivasi yang menarik agar peserta didik lebih fokus mengikuti pembelajaran. Kemudian, guru memonitoring kegiatan peserta didik dalam berkelompok dan mengkoordinir peserta didik agar ikut berkontribusi dalam kelompoknya. Selain itu juga memberikan tambahan waktu untuk presentasi hasil diskusi agar peserta didik dapat berdiskusi lagi jika ada perbedaan pendapat. Hasil penelitian tersebut menunjukkan bahwa penerapan model pembelajaran Problem Based Learning dapat meningkatkan hasil belajar kognitif peserta didik kelas X MIPA-3 SMA N 1 Kembang.
\end{abstract}

Kata kunci: hasil belajar kognitif, problem based learning

\begin{abstract}
This study aims to determine the cognitive learning outcomes of students using the Problem Based Learning (PBL) learning model. The type of research used is Classroom Action Research (CAR) with a qualitative approach. This research was conducted online through Google Meet and Whatsapp Group for two cycles. The research activities include planning, implementation, observation/evaluation and reflection. The subjects of this study were students of class X MIPA-3 SMAN 1 Kembang. Data collection techniques using tests and interviews are then analyzed qualitatively. The results obtained are that in Cycle I there are $57 \%$ of students who reach the criteria of completeness and an increase in Cycle II as much as $77 \%$ of students who have achieved the criteria of completeness. The increase in the criteria for completeness can occur because the teacher provides interesting motivation so that students are more focused on participating in learning. Then, the teacher monitors the activities of students in groups and coordinates students to contribute to the group. In addition, it also provides additional time for presentation of the results of the discussion so that students can discuss again if there are differences of opinion. The results of this study indicate that the application of the Problem Based Learning learning model can improve the cognitive learning outcomes of students in class X MIPA-3 SMA N 1 Kembang.
\end{abstract}

Keywords: cognitive learning outcomes, problem based learning 


\section{Pendahuluan}

Pandemi Covid-19 pada awal tahun 2020 menyebabkan seluruh kegiatan pembelajaran di sekolah yang awalnya dilaksanakan secara tatap muka beralih menjadi pembelajaran jarak jauh. Menteri Pendidikan dan Kebudayaan Indonesia mengeluarkan Surat Edaran No.4 Tahun 2020 pada tanggal 24 Maret 2020 yang berisi tentang Pelaksanaan Kebijakan Pendidikan dalam Masa Darurat Penyebaran Covid-19 [1]. Dalam surat edaran dijelaskan bahwa proses pembelajaran dilakukan di rumah melalui daring (dalam jaringan) atau jarak jauh tanpa bertatap muka langsung dengan peserta didik. Perubahan proses pembelajaran ini dilakukan dengan tujuan untuk mencegah penyebaran virus Covid-19, dimana virus ini dapat menyebar melalui muntah (fomites), maupun tetesan air liur (droplets) dalam kontak dekat tanpa pelindung.

Proses pembelajaran secara daring atau jarak jauh membuat guru dan peserta didik harus menguasai teknologi dan aplikasi yang dapat menunjang kegiatan belajar. Beberapa aplikasi yang dapat membantu proses pembelajaran yaitu Whatsapp, Google Classroom, Google Meet, Zoom dan Quipper. Selain itu jaringan internet juga menjadi salah satu modal utama yang menunjang berlangsungnya proses pembelajaran. Meskipun proses pembelajaran yang dilakukan saat ini berbeda dari biasanya, namun siswa tetap memiliki kesempatan yang sama untuk berprestasi [2].

Berdasarkan hasil wawancara dengan peserta didik, terdapat beberapa kendala selama pembelajaran daring, yaitu jaringan internet yang tidak stabil, pulsa kuota yang dimiliki terbatas, kurang menguasai aplikasi yang digunakan, guru lebih banyak memberi tugas daripada memberi penjelasan dan berdiskusi sehingga peserta didik merasa lebih tertarik mengikuti pembelajaran tatap muka. Kondisi tersebut membuat seorang guru harus melakukan inovasi untuk memilih media dan model pembelajaran yang efektif selama pembelajaran daring ini. Supriyani menyatakan bahwa "penggunaan media pembelajaran selama proses pembelajaran dapat meningkatkan minat belajar dan memberi rangsangan kegiatan belajar serta dapat membawa pengaruh-pengaruh psikologis terhadap siswa" [3]. Salah satu faktor lain yang dapat berpengaruh terhadap hasil belajar peserta didik yaitu penggunaan model pembelajaran yang tepat.

Salah satu model pembelajaran yang dapat meningkatkan hasil belajar peserta didik yaitu model pembelajaran Problem Based Learning. Pembelajaran Berbasis Masalah atau Problem Based Learning (PBL) adalah salah satu model pembelajaran inovatif yang memberikan kondisi belajar aktif kepada peserta didik [4]. Utrifani menjelaskan bahwa "PBL merupakan model pembelajaran yang melibatkan peserta didik untuk memecahkan suatu masalah melalui tahap metode ilmiah sehingga peserta didik dapat mempelajari pengetahuan yang berhubungan dengan masalah tersebut serta memiliki keterampilan untuk memecahkan masalah" [5]. Arends menyatakan bahwa "PBL adalah pembelajaran yang memiliki esensi berupa penyuguhan berbagai bermasalah yang autentik dan bermakna kepada peserta didik, yang dapat berfungsi sebagai sarana untuk melakukan investigasi dan penyelidikan" [6]. Komalasari mengatakan bahwa "PBL adalah model pembelajaran yang menggunakan masalah dunia nyata sebagai suatu konteks bagi peserta didik untuk belajar tentang berpikir kreatif dan keterampilan pemecahan masalah, serta untuk memperoleh pengetahuan dan konsep yang esensi dari mata pelajaran" [7]. Adapun langkah-langkah model PBL sebagai berikut: (1) orientasi peserta didik kepada masalah (2) membimbing pengalaman individual/kelompok (3) mengembangkan dan menyajikan hasil karya. (4) menganalisis dan mengevaluasi prosespemecahan masalah [8].

Suryawan [9] menyatakan bahwa "prestasi belajar yang lebih tinggi diraih oleh peserta didik yang menerima perlakuan model PBL (Problem Based Learning atau Pembelajaran Berbasis Masalah). Prestasi belajar siswa diakibatkan oleh perbedaan model pembelajaran. Prestasi belajar yang lebih tinggi diraih oleh siswa yang menerima perlakuan model PBL (Problem Based Learning atau Pembelajaran Berbasis Masalah). Perbedaan prestasi belajar siswa juga diakibatkan oleh perbedaan motivasi berprestasi. Prestasi belajar yang lebih tinggi diraih oleh siswa yang memiliki MBT (Motivasi Berprestasi Tinggi). Akhirnya, ada pengaruh interaktif antara model pembelajaran dan motivasi berprestrasi terhadap prestasi belajar siswa".

Kemudian, Helyandari [10] menyatakan bahwa "terdapat pengaruh model Problem Based Learning pada hasil belajar fisika peserta didik MA Darul Hikmah Tahun Ajaran 2019/2020. Model Problem Based Learning yang diterapkan pada kelas eksperimen memiliki keunggulan berupa peserta didik dapat membiasakan diri menghadapi dan memecahkan masalah secara terampil, dapat merangsang dan mengembangan kemampuan berpikir secara kreatif dan menyeluruh dalam proses pembelajaran peserta didik dilatih untuk menyoroti permasalahan dari berbagai aspek. Kegiatan pembelajaran pada kelas eksperimen 
dirancang berdasarkan karakteristik model pembelajaran PBL yang tercermin didalam langkah pembelajaran tersebut".

Nora [11] menyatakan bahwa "pengaruh Problem Based Learning masuk kategori tinggi terhadap hasil belajar siswa kelas X dan kelas XI". Pengaruh penggunaan model pembelajaran berbasis masalah pada tingkat kelas X dengan rata-rata 1,22 dalam kategori sangat tinggi. Padahal, pada tingkat kelas XI dengan rata-rata 1,95 masuk dalam kategori sangat tinggi. Kedua, pengaruh pembelajaran berbasis masalah terhadap dinamika listrik, gerak, panas dan suhu, dan geometri optik tinggi. Apalagi Hukum Newton sangat tinggi. Ketiga, pengaruh model pembelajaran berbasis masalah, terhadap aspek pengetahuan termasuk dalam kategori sangat tinggi, aspek keterampilan berpikir kritis termasuk kategori tinggi, dan aspek keterampilan pemecahan masalah termasuk dalam kategori tinggi.

Penelitian yang dilakukan oleh beberapa ahli tersebut dilaksanakan secara tatap muka dan berpengaruh terhadap hasil belajar peserta didik. Oleh karena itu, peneliti mencoba menerapkan model pembelajaran Problem Based Learning secara daring. Karena proses pembelajaran sebelum masa pandemi selalu dilaksanakan secara tatap muka dan melibatkan interaksi langsung antara guru dan peserta didik. Pada observasi awal diperoleh kondisi peserta didik kelas X MIPA-3 SMA N 1 Kembang memiliki hasil belajar kognitif yang tergolong rendah. Hal ini ditandai dengan persentase peserta didik yang memperoleh nilai di atas Kriteria Ketuntasan Minimum (KKM) lebih kecil daripada peserta didik yang tuntas KKM. Berdasarkan wawancara dengan peserta didik kondisi tersebut disebabkan oleh rendahnya motivasi belajar peserta didik selama pembelajaran jarak jauh berlangsung. Peserta didik cenderung pasif selama diskusi dalam pembelajaran berlangsung. Kemudian, peserta didik hanya belajar jika ada tugas dan menjelang ulangan, tidak ada inisiatif mempelajari lagi materi yang sudah diajarkan oleh guru. Disisi lain juga masih terdapat banyak kasus peserta didik terlambat dalam mengumpulkan tugas. Sebagian besar peserta didik menyatakan tidak semangat mengikuti pembelajaran karena tidak berinteraksi langsung dengan guru. Selain itu banyak peserta didik yang lokasi rumahnya tidak memiliki akses jaringan internet yang stabil sehingga tidak dapat mengikuti pembelajaran dengan baik.

Berdasarkan uraian latar belakang di atas perlu diadakan tindakan pada kelas X MIPA 3 SMA N 1 Kembang dengan menerapkan model pembelajaran Problem Based Learning yang kemudian dituangkan dalam bentuk penelitian dengan judul "Penerapan Model Pembelajaran Problem Based Learning untuk Meningkatkan Hasil Belajar Peserta Didik SMA N 1 Kembang”. Penilitian ini bertujuan untuk mengetahui peningkatan hasil belajar kognitif peserta didik menggunakan model pembelajaran Problem Based Learning.

\section{Metode Penelitian}

Penelitian dilaksanakan di SMA Negeri 1 Kembang pada peserta didik kelas X MIPA 3 Tahun Ajaran 2020/2021. Jenis penelitian yang digunakan adalah Penelitian Tindakan Kelas (PTK) dengan menganut desain penelitian yang dikembangkan oleh Kemmis dan Mc. Taggart yang terdiri dari empat komponen yaitu tahap perencanaan (plan), pelaksanaan (act), pengamatan (observe) dan refleksi (reflect) [12]. Kegiatan yang dilakukan pada tahap perencanaan yaitu: 1) menyusun Rencana Pelaksanaan Pembelajaran (RPP) meliputi langkah-langkah proses pembelajaran dengan model PBL dan Lembar Kerja Peserta Didik (LKPD), 2) menyusun lembar observasi peserta didik pada setiap proses pembelajaran, 3) menyusun pertanyaan untuk wawancara dengan peserta didik dan 4) menyusun soal tes yang akan diberikan pada setiap akhir siklus.

Pada tahap pelaksanaan dan pengamatan dilakukan secara bersamaan. Guru melaksanakan proses pembelajaran sesuai dengan RPP model PBL yang telah disusun secara daring melalui Google Meet. Proses observasi juga dilakukan oleh guru dengan mengamati motivasi belajar peserta didik selama proses pembelajaran. Proses observasi dilaksanakan secara daring dengan ikut bergabung dalam ruang diskusi kelompok melalui Whatsapp Group. Kemudian, di akhir pembelajaran dilakukan tes dan wawancara dengan siswa.

Selanjutnya, kegiatan refleksi merupakan kegiatan yang sangat penting yang bertujuan untuk mengevaluasi hasil tindakan yang telah dilakukan dengan melihat apa yang masih perlu diperbaiki, ditingkatkan atau dipertahankan. Tindakan ini merupakan salah satu bentuk evaluasi terhadap diri sendiri. Dari hasil refleksi tersebut dicari solusinya kemudian dilanjutkan pada siklus berikutnya. Pada tahap ini peneliti mengumpulkan semua data yang diperoleh selama observasi yaitu data hasil tes peserta didik, pengamatan 
motivasi belajar peserta didik, dan wawancara dengan peserta didik mengenai proses pembelajaran yang telah berlangsung.

Pembelajaran ini dapat dinyatakan berhasil apabila 75\% dari jumlah peserta didik di kelas mendapat nilai tes diatas Kriteria Ketuntasan Minimum (KKM). Adapun Kriteria Ketuntasan Minimum untuk mata pelajaran fisika di SMAN 1 Kembang adalah 68. KKM berfungsi sebagai patokan guru dalam menilai kompetensi peserta didik sesuai kompetensi dasar mata pelajaran yang diikuti [13]. Peserta didik dianggap tuntas belajar bila memperoleh nilai sama dengan atau lebih besar dari nilai KKM [14].

\section{Hasil Penelitian dan Pembahasan}

Penelitian diawali dengan melakukan observasi hasil belajar kognitif peserta didik selama pembelajaran jarak jauh berlangsung. Kemudian, untuk mendukung data hasil belajar kognitif peserta didik juga dilakukan wawancara secara daring dengan peserta didik. Hasil observasi menunjukkan bahwa hasil belajar kognitif peserta didik kelas X MIPA-3 SMAN 1 Kembang masih tergolong rendah. Kondisi ini sesuai dengan jumlah peserta didik yang belum tuntas KKM lebih banyak daripada yang mencapai KKM. Kemudian, berdasarkan wawancara dengan peserta didik diperoleh keterangan bahwa peserta didik merasa jenuh dengan kondisi belajar daring secara terus menerus yang tidak ada interaksi dengan guru dan teman sebayanya. Selain itu sebagian besar peserta didik menyatakan bahwa letak rumahnya tidak memiliki akses jaringan internet yang stabil. Kurangnya pengawasan dari orangtua juga mengakibatkan peserta didik merasa malas untuk mengikuti pembelajaran secara daring. Adapun hasil belajar kognitif peserta didik dapat dilihat pada Tabel 1. Berdasarkan keterangan yang diperoleh dari wawancara dapat disimpulkan bahwa motivasi belajar peserta didik masih rendah sehingga hasil belajar yang diperoleh tidak maksimal. Sucipta menyatakan bahwa "permasalahan yang dihadapi siswa tersebut berdampak pada nilai yang diperoleh siswa" [2]. Kemudian menurut Rerung "pada saat belum di lakukan tindakan tidak ada peserta didik yang tuntas. Hal ini dikarenakan peserta didik sama sekali belum diajarkan materinya" [15].

Tabel 1. Tabel Hasil Belajar Kognitif Peserta Didik Sebelum Tindakan/ Pra Siklus

\begin{tabular}{lc}
\multicolumn{1}{c}{ Keterangan } & Pra Siklus \\
\hline Nilai Terendah & 11 \\
Nilai tertinggi & 80 \\
Peserta didik Tuntas & 16 \\
Peserta didik Tidak Tuntas & 19 \\
\hline Rata-rata & 55,97 \\
\hline Persentase Ketuntasan & $46 \%$ \\
\hline
\end{tabular}

Kriteria Ketuntasan Minimun (KKM) di SMA N 1 Kembang untuk mata pelajaran Fisika adalah 68. Berdasarkan hasil tes yang diperoleh menunjukkan bahwa hasil belajar peserta didik masih tergolong rendah sebanyak 19 peserta didik belum mencapai KKM. Jika dituliskan dalam bentuk persentase sebanyak 54\% peserta didik belum mencapai KKM. Oleh karena itu, perlu suatu tindakan dengan menerapkan model pembelajaran Problem Based Learning yang diharapkan mampu meningkatkan hasil belajar kognitif peserta didik. Perbandingan hasil belajar kognitif peserta didik sebelum dilakukan tindakan dan setelah dilakukan tindakan pada Siklus 1 dan Siklus 2 dapat dilihat pada Tabel 2.

Tabel 2. Perbandingan Hasil Belajar Kognitif Peserta Didik

\begin{tabular}{lccc}
\hline Keterangan & Pra Siklus & Siklus I & Siklus II \\
\hline Nilai Terendah & 11 & 10 & 20 \\
Nilai tertinggi & 80 & 90 & 90 \\
Peserta didik Tuntas & 16 & 20 & 27 \\
Peserta didik Tidak Tuntas & 19 & 15 & 8 \\
\hline Rata-rata & 55,97 & 59,14 & 68,86 \\
\hline Persentase Ketuntasan & $46 \%$ & $57 \%$ & $77 \%$ \\
\hline
\end{tabular}


Tindakan Siklus 1 dilaksanakan saat materi pembelajaran momentum dan impuls. Berdasarkan hasil belajar kognitif peserta didik yang diperoleh melalui teknik tes menunjukkan bahwa hasil belajar peserta didik masih tergolong rendah, dari 35 peserta didik hanya sebanyak 20 peserta didik telah mencapai KKM. Jika dituliskan dalam bentuk persentase baru sebanyak 57\% peserta didik telah mencapai KKM.

Refleksi yang dialami selama pelaksanaan tindakan Siklus 1 ini yaitu masih banyak peserta didik yang tidak mengikuti pembelajaran karena beberapa kendala seperti akses jaringan internet yang tidak stabil. Selain itu peserta didik juga tidak memperhatikan dengan baik topik pembelajaran yang dibahas. Kendala lainnya yaitu peserta didik tidak aktif menyampaikan pendapatnya selama diskusi berlangsung. Kemudian, masih terdapat banyak peserta didik yang telat dalam mengumpulkan tugas. Kendala-kendala tersebut menyebabkan peserta didik kurang memahami topik pembelajaran sehingga peserta didik mengalami kesulitan dalam mengerjakan tes. Oleh karena itu, hasil belajar kognitif peserta didik tidak maksimal. Berdasarkan data hasil belajar peserta didik kelas X MIPA-3 SMA N 1 Kembang pada pelaksanaan tindakan Siklus I menunjukkan bahwa tindakan yang dilakukan belum mencapai target indikator keberhasilan. Berdasarkan hasil refleksi dalam pelaksanaan tindakan Siklus I dapat diperbaiki pada tindak lanjut Siklus II.

Rencana perbaikan yang akan dilaksanakan pada Siklus II yaitu dengan menghimbau siswa untukmencari lokasi yang memiliki jaringan internet stabil ketika proses pembelajaran berlangsung, kemudian guru memberikan motivasi kepada peserta didik yang lebih menarik dan jelas agar peserta didik lebih fokus dalam mengikuti pembelajaran dan memperhatikan dengan baik topik pembelajaran yang dibahas. Kemudian, pada saat peserta didik bertanya ketika menemukan kesulitan dalam menyelesaikan analisis data guru tidak langsung menjawab pertanyaan tersebut tetapi dikembalikan lagi ke peserta didik untuk didiskusikan bersama-sama dengan memberikan arahan. Proses diskusi tersebut diharapkan dapat meningkatkan keaktifan siswa dalam menyampaikan pendapatnya. Selanjutnya, memonitoring kegiatan peserta didik dalam berkelompok dan mengkoordinir peserta didik agar ikut berkontribusi dalam kelompoknya. Selain itu juga memberikan tambahan waktu untuk presentasi hasil diskusi agar peserta didik dapat berdiskusi lagi jika ada perbedaan pendapat. Guru juga menghimbau peserta didik untuk mengumpulkan tugas tepat waktu.

Tindakan Siklus II dilaksanakan pada materi jenis-jenis tumbukan. Berdasarkan hasil observasi yang dilakukan pada Siklus II peserta didik lebih memahami topik pembelajaran dan mulai terbiasa dengan model pembelajaran Problem Based Learning yang digunakan. Kegiatan diskusi kelompok menjadi aktif karena guru ikut memonitoring diskusi dalam Whatsapp Group tiap kelompok. Peserta didik tidak takut menyampaikan pendapatnya sehingga lebih aktif dalam mengikuti pembelajaran. Peserta didik juga menjadi lebih fokus selama pembelajaran berlangsung.

Hasil belajar kognitif peserta didik yang diperoleh melalui teknik tes diperoleh sebanyak 27 peserta didik telah mencapai KKM. Jika dituliskan dalam bentuk persentase sebanyak $77 \%$ peserta didik telah mencapai KKM. Pada tindakan Siklus II ini telah mencapai target keberhasilan penelitian. Hasil tindakan Siklus II menunjukkan terjadi peningkatan hasil belajar kognitif peserta didik kelas X MIPA-3 SMA N 1 Kembang. Dengan adanya hal tersebut, maka tindakan dalam penelitian ini telah dinyatakan berhasil dan dihentikan pada Siklus II.

Hasil pengamatan dan analisis data menunjukkan terdapat peningkatan hasil belajar kognitif peserta didik. Peningkatan tersebut terlihat dari sebelum adanya tindakan atau Pra-Siklus dan setelah tindakan, yaitu Siklus I dan Siklus II. Perbandingan peningkatan pencapaian hasil belajar peserta didik Siklus I dan Siklus II pada kelas X MIPA-3 SMA N 1 Kembang dapat dilihat pada Gambar 1. 


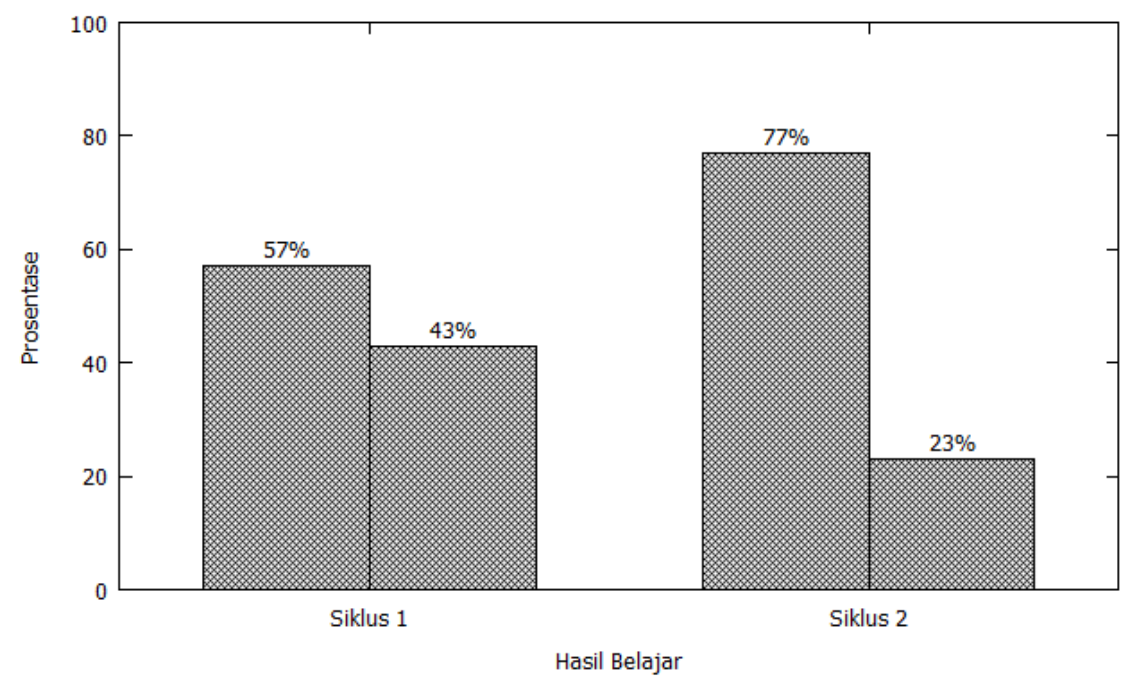

Gambar 1. Bagan Hasil Belajar Kognitif Peserta Didik

Gambar tersebut menunjukkan bahwa ada peningkatan hasil belajar kognitif peserta didik dari Siklus I ke Siklus II. Pada Siklus I terdapat 57\% peserta didik yang mencapai kriteria ketuntasan sedangkan pada Siklus II terdapat $77 \%$ peserta didik yang mencapai kriteria ketuntasan. Hal tersebut menunjukkan bahwa penerapan model pembelajaran Problem Based Learning dapat meningkatkan hasil belajar kognitif peserta didik kelas X MIPA-3 SMA N 1 Kembang.

\section{Kesimpulan}

Berdasarkan analisis data dan pembahasan dari penerapan model pembelajaran Problem Based Learning dalam pembelajaran Fisika di kelas X MIPA-3 SMA N 1 Kembang Tahun Ajaran 2020/2021 dengan jenis Penelitian Tindakan Kelas (PTK) dapat ditarik kesimpulan bahwa model pembelajaran Problem Based Learning mampu meningkatkan hasil belajar kognitif peserta didik. Pada Siklus I terdapat 57\% peserta didik yang mencapai kriteria ketuntasan sedangkan pada Siklus II terdapat $77 \%$ peserta didik yang mencapai kriteria ketuntasan.

\section{Kepustakaan}

[1] Wiryanto, "Proses Pembelajaran Matematika Di Sekolah Dasar Di Tengah Pandemi Covid-19," J. Rev. Pendidik. Dasar J. Kaji. Pendidik. dan Has. Penelit., vol. 6, no. 2, pp. 125-132, 2020.

[2] I. W. Sucipta, "Penerapan Model Pembelajaran STAD dengan Menggunakan Media Pembelajaran dalam Meningkatkan Hasil Belajar Fisika Siswa Kelas Xii Mipa 8 Sma Negeri 7 Denpasar Tahun Pelajaran 2020 / 2021,” Widyadari, vol. 22, no. 1, pp. 102-114, 2021, doi: 10.5281/zenodo.4661220.

[3] Y. Supriani, "Menumbuhkan Kemandirian Belajar Matematika Siswa Berbantuan Quipper School," J. Ilm. Pendidik. Mat., vol. 1, no. 2, pp. 210-220, 2016.

[4] A. K. Nisa, "Implementasi Model Pembelajaran Problem Based Learning untuk Meningkatkan Keaktifan dan Hasil Belajar Siswa Pada Mata Pelajaran Pemrograman Desktop Kelas XI RPL SMK Ma’arif Wonosari Tugas,” 2015.

[5] A. Utrifani and B. Turnif, M, "Pengaruh Model Pembelajaran Problem Based Learning Terhadap Hasil Belajar Siswa Pada Materi Pokok Kinematika Gerak Lurus Kelas X SMA Negeri 14 Medan T.P.2013/2014,” J. Inpafi, vol. 2, no. 2, pp. 9-16, 2014.

[6] R. . Arends, Learning To Teach. 2008.

[7] K. Komalasari, Pembelajaran Kontekstual : Konsep dan Aplikasi. 2013.

[8] A. Elizabeth and M. M. Sigahitong, "Pengaruh Model Problem Based Learning Terhadap Kemampuan Berpikir Kreatif Peserta Didik SMA," Prism. Sains J. Pengkaj. Ilmu dan Pembelajaran Mat. dan IPA IKIP Mataram, vol. 6, no. 2, pp. 66-76, 2018, doi: 10.33394/j-ps.v6i2.1044.

[9] I. M. Y. Suryawan, I. W. Santyasa, and I. G. A. Gunadi, "Keefektifan Model Problem Based Learning dan Motivasi Berprestasi Siswa dalam Pencapaian Prestasi Belajar Fisika," Mimb. Pendidik. J. Indones. untuk Kaji. Pendidik., vol. 4, no. 1, pp. 35-54, 2019, doi: 10.17509/mimbardik.v4i1.16969. 
[10] B. H. Helyandari, H. Sahidu, and Hikmawati, "Pengaruh Model Problem Based Learning Terhadap Hasil Belajar," KONSTAN J. Fis. DAN Pendidik. Fis., vol. 5, no. 1, pp. 10-17, 2020, doi: 10.37905/aksara.5.1.39-46.2019.

[11] A. Nora and Asrizal, "Meta Analysis of The Influence of Problem Based Learning Models in High School Physics Students on Student Learning Outcomes," Pillar Phys. Educ., vol. 13, no. 4, pp. 494-501, 2020.

[12] Daryanto, Penelitian Tindakan Kelas dan Penelitian Tindakan Sekolah. 2014.

[13] T. G. Ratumanan and Laurens, Penilaian Hasil Belajar pada Tingkat Satuan Pendidikan Edisi 2. 2011.

[14] N. Devi, D. Wahyuni, and P. Jekti, "Pembelajaran Model Pembelajaran Berbasis Masalah (Problem Based Learning) Dilengkapi Teknik Mind Mapping Terhadap Peningkatan Motivasi dan Hasil Belajar Siswa SMAN 1 Pakusari Jember Pokok Bahasan Jamur Kelas X Semester Gasal Tahun Ajaran 2013/2014," J. Pancar., vol. 4, no. 2, pp. 3548, 2015.

[15] N. Rerung, I. L. S. Sinon, and S. W. Widyaningsih, "Penerapan Model Pembelajaran Problem Based Learning (PBL) untuk Meningkatkan Hasil Belajar Peserta Didik SMA pada Materi Usaha dan Energi," J. Ilm. Pendidik. Fis. AlBiruni, vol. 6, no. 1, pp. 47-55, 2017, doi: 10.24042/jpifalbiruni.v6i1.597. 